\title{
THE TOOLS OF QUALITATIVE APPROACH TO MEASURE RURAL TRANSFORMATION: THE CASE OF YOGYAKARTA RURAL VILLAGE
}

\author{
Anna Pudianti ${ }^{1}$, Atiek Suprapti ${ }^{1}$, and Joesron Ali Syahbana ${ }^{1}$
}

Received: October $31^{\text {st }} 2018$

Accepted: March $8^{\text {th }} 2019$

\begin{abstract}
Yogyakarta is one of the rapidly growing Indonesian cities with its strong culture to construct a distinctive transformation, especially in the rural area. The process of transformation in the rural areas is a continuous process as a form of the desire to grow. The agricultural based rural area diversify into activities other than agriculture, such as small craft industry and rural tourism. This study aims to explore tools to measure the level of transformation with a qualitative approach. The uniqueness of the transformation process in the rural area of Yogyakarta inspires the preparation of transformation measurement tools with qualitative approach by using eight indicators to produce depth of findings. The tools are developed by using a quadrant model of the combination of potential resources with the efforts made by the occupants. Since the case study research is being used to for the analysis, the quantitative approach could be also used to validate the result of the tools. The quantitative data is taken from secondary data of satellite imagery, government institution and field survey. Furthermore, this research provides interesting findings by its comparative study between qualitative and quantitative approach. The qualitative approach can become a tool for explaining the dynamics of the transformation of rural area as a whole, complementing quantitative results.
\end{abstract}

Keyword: rural transformation, qualitative approach, quadrant model

\section{INTRODUCTION}

Sustainability issue was very important for the future (Kuhn, 2008) and as we knew that, the transformation has to happen. But the level of transformation in a place could be varied in a sense of development (Long et al., 2011), including in the rural areas such as in China (Chen, Lin and Kuo, 2013), (Su et al., 2011), in the Philippines (Gibson, Cahill and Mckay, 2010) in Indonesia, and Nepal (Rana and Marwasta, 2015). (Long et al., 2011)classified the rural development level based on three factors, which are the rural economic, agricultural production investment, and rural livelihood. The indicator used to measure the rural economic are the agricultural output value level and the productivity of rural labour, and for agricultural production investment the indicators are power investment, fertilizer investment, and irrigation index, and the rural livelihood are indicated by rural electricity consumption, rural income level, and rural consumption level. Long's classification of the rural development based on quantitative approach were stagnation development that are being divided into low, intermediate-low, intermediate-high, high, and extremely high statistically.

As long as the data is available, the quantitative approach is easier and clearer to develop. But in measuring the transformations, especially in rural areas, there are things that are not quantitatively measurable. Therefore, a qualitative transformation

\footnotetext{
${ }^{1}$ Doctoral Program of Architecture and Urbanism Program, Diponegoro University
} 
measurement approach is needed to be developed to explore the intangibles. The intangible data on rural areas is more related to rural livelihood such as the willingness to develop their home land, the model and quality of local leader, community participation, the way rural community carry out the new comer who brings the change, and the villagers' network. These data should be able to be de-composed and grouped in order to become measurable.

Based on various research that has been done, there are a number of factors that affect the transformation. Potential rural areas will greatly affect the transformation (Ezung, 2011), (Hernández-Maestro, Muñoz-Gallego and Santos-Requejo, 2009) and determine the type and quality of the transformations. There are also two distinctly rural factors, namely the tenacity of local leaders (Nair, Mohamed and Chiun, 2015); (Rattanasuwongchai, 1998) and the community willingness to support the transformation; (Dogra and Gupta, 2012); (Reid, Mair and Taylor, 2000). However, (Yun, 2014) and (Green, 2001) also mentioned the significance of amenity in the sustainability of a region's economic development. And unique amenities will be recognized by communities outside the area through marketing or promotion (Chen, Lin and Kuo, 2013), (Hernández-Maestro, Muñoz-Gallego and SantosRequejo, 2009) intentionally or unintentionally, on people who have experienced the pleasure and comfort due to the amenity existed in a region. One of the most compulsory good amenity is accessibility (McGee, 2008); (Dluzewska and Dluzewski, 2017) which because of its great influence over other types of amenities, can be a separate factor that can affect transformation. Access to rural areas and their proximity to urban areas increased rural potential 1) as the main staple food supply area, 2) as a raw material and productive workforce and 3) in terms of work activities, can develop into industrial villages and tourist villages (Arsyad, L., Satriawan, E., Mulyo, J.H., \& Fitrady, 2011). From the economic side, the total revenue generated will also determine the sustainability of the transformation process (Rattanasuwongchai, 1998). While asset ownership [8] used in the transformation process is also an important factor to be considered.

From the literature review, there are eight indicators that can be used, which are 1) rural potential and appeal, 2) managerial capacity of the village, 3) community participation, 4) ease, 5) marketing and promotion 6) accessibility, 7) total revenue produced, and 8) asset ownership. Most of the above indicators use quantitative approach, and only a small part of them applies a qualitative approach. This study aims to explore tools to measure the level of transformation with a qualitative approach. The eight indicators that are being used are expected to reflect the transformation phase in rural areas more deeply, precisely, and integrated.

In Indonesia, rural areas are scattered in a variety of geographic conditions, such as mountainous areas, coastal areas, inland or remote areas, so this research is applied with case study research using multi-case study research in Yogyakarta. Yogyakarta has the fourth highest migration in Indonesia between 1990-2010 (Biro Pusat Statistik, 2010). It is also the best representation in the transformation process because of the transformation experience from a monarchy city into becoming a city with special rights of royal-based government system. It is a very dynamic field of development, while on the other hand it retains the Javanese cultural aspect.

This study aims to explore tools to measure the level of transformation with a qualitative approach. The tools to measure the rural transformation could be used by the government to evaluate the power of transformation in each case. And it could be a strategic decision to re-arrange the village grant effectively. 


\section{Method}

The level of transformation was not based on only location, but the combination between location and culture (Pudianti, Anna; Syahbana, Joesron Alie; Suprapti, 2015). So this case study research based on (Yin, 2009) was using four (4) cases in Daerah Istimewa Yogyakarta. Two cases are chosen to represented rural areas that have transformed into natural resource-based and rural-based ecotourism villages, and two other cases are the areas that have transformed into handicraft villages. The use of these four cases is expected to complete each other into a generalized result based on the variation location, culture and the level of transformation in each villages. Those rural villages are Gabungan and Pentingsari (in Sleman Region), which are both transformed into rural tourism, and Kasongan and Manding (in Bantul Region) which are the cases of industrial rural transformation (figure 1).

Pentingsari is a tourist village in the north of Yogyakarta, $20 \mathrm{~km}$ from Yogyakarta city and located on the slopes of Mount Merapi. It has an attractive nature of a green village with local cultural heritage. The second village is Gabugan, which has strong local culture that comes from the noble culture, but now has been transformed to become a tourist village. It is located approximately $16 \mathrm{~km}$ from the city of Yogyakarta and $4 \mathrm{~km}$ from the city of Sleman. The other two villages, Kasongan and Manding, are the industrial rural areas, and both are located in the lowlands. Kasongan is located in about $8 \mathrm{~km}$ to the southwest of the centre of Yogyakarta and Manding is about $15 \mathrm{~km}$ from the Yogyakarta to the south. Kasongan is the village specializing in pottery industry and Manding is a village specializing in leather craft.

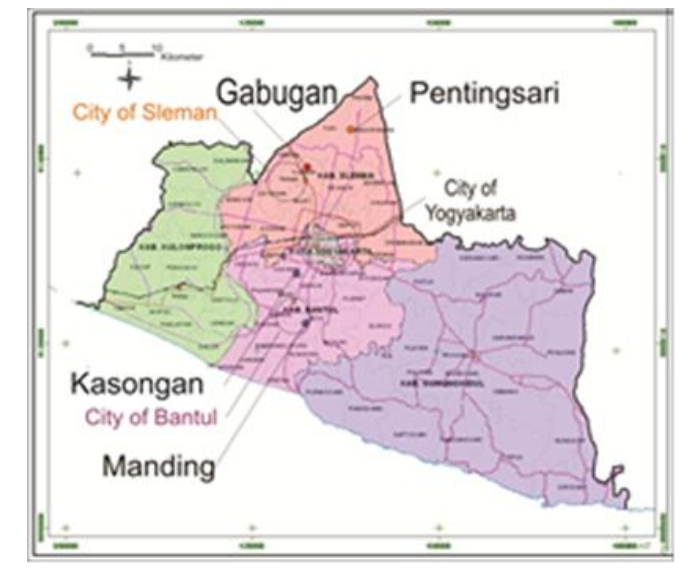

Figure 1. The map of Daerah Istimewa Yogyakarta and the four study cases

Based on the data availability to crosscheck the result of qualitative analysis using the map of built-up area, the transformation research was limited to the period between the years 2000 until 2016. Even though the Kasongan and Manding villages have transformed for more than one decade, the research explored only the transformation of the last decade.

In order to measure the transformation of the rural areas using multi case study research qualitatively, four villages of Yogyakarta have been chosen based on its characters (table 1). The data of qualitative method is taken by in-depth interview and observation to each of the four villages. 
Table 1. The characteristic of case study

\begin{tabular}{|c|c|c|c|}
\hline \multicolumn{2}{|c|}{ Tourism Village } & \multicolumn{2}{|c|}{ Traditional Industrial Village } \\
\hline Pentingsari & Gabugan & Manding & Kasongan \\
\hline $\begin{array}{l}\text { Rural nature and } \\
\text { culture tourism } \\
\text { (education) }\end{array}$ & $\begin{array}{l}\text { Rural culture } \\
\text { (education) }\end{array}$ & $\begin{array}{l}\text { Rural industry of leather } \\
\text { craft village }\end{array}$ & $\begin{array}{l}\text { Rural industry of } \\
\text { pottery craft } \\
\text { village }\end{array}$ \\
\hline $\begin{array}{l}\text { The chalenge of } \\
\text { isolated location }\end{array}$ & $\begin{array}{l}\text { The chalenge of noble } \\
\text { culture }\end{array}$ & $\begin{array}{l}\text { The chalenge of resource } \\
\text { (agriculture and skill of the } \\
\text { people) }\end{array}$ & $\begin{array}{l}\text { The chalenge of } \\
\text { resource (agriculture } \\
\text { and skill of the people) }\end{array}$ \\
\hline $\begin{array}{l}\text { Public and private } \\
\text { grant after the village } \\
\text { transformation }\end{array}$ & $\begin{array}{l}\text { Public and private grant } \\
\text { during the } \\
\text { transformation }\end{array}$ & $\begin{array}{l}\text { Public and private grant } \\
\text { after the transformation } \\
\text { and during the } \\
\text { development }\end{array}$ & $\begin{array}{l}\text { Expert help during the } \\
\text { transformation and } \\
\text { during development }\end{array}$ \\
\hline $\begin{array}{l}8 \text { years period of } \\
\text { transformation }(2008- \\
2016)\end{array}$ & $\begin{array}{l}11 \text { years period of } \\
\text { transformation }(2005- \\
2016)\end{array}$ & $\begin{array}{l}16 \text { years period of } \\
\text { transformation }(2000-2016)\end{array}$ & $\begin{array}{l}7 \text { years period of } \\
\text { transformation (2009- } \\
2016)\end{array}$ \\
\hline
\end{tabular}

Source: Analysis, 2018

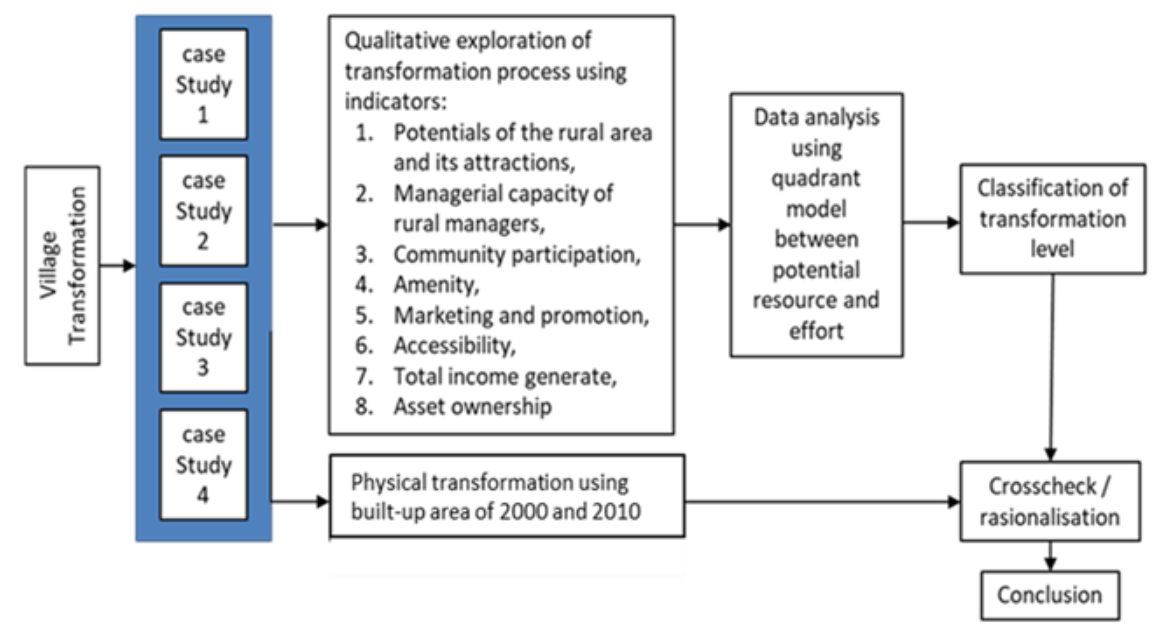

Source: Analysis, 2018

Figure 2. Diagram of analysis process

The process of analysis shown in figure 2 carried out a short descriptive analysis of each case study. The first step was describing the condition of each indicator in transformation process, and it aimed to explore the potential resources and the efforts of its indicator. After having the conclusion of its condition, each indicator should be placed in quadrant model of analysis (figure 3) to classify the transformation level. To count the value level of transformation, each of the indicator got a point of 1 up to 4 which represented value of the quadrant. The first quadrant (I) has 4 point, the second quadrant (II) 3 point, third quadrant (III) 2 point and the fourth quadrant (IV) 1 point, so each village get a final transformation value from the sum of every point of the eight indicators. To complete the result, the quantitative approach was applied by physical transformation maps of 2000 and 2010. The physical transformation was interpreted from the built-up area from the secondary data of satellite imagery. The built-up area describes the context of 
change in the area surrounding the village that are being studied so that it could be discussed between those two results.

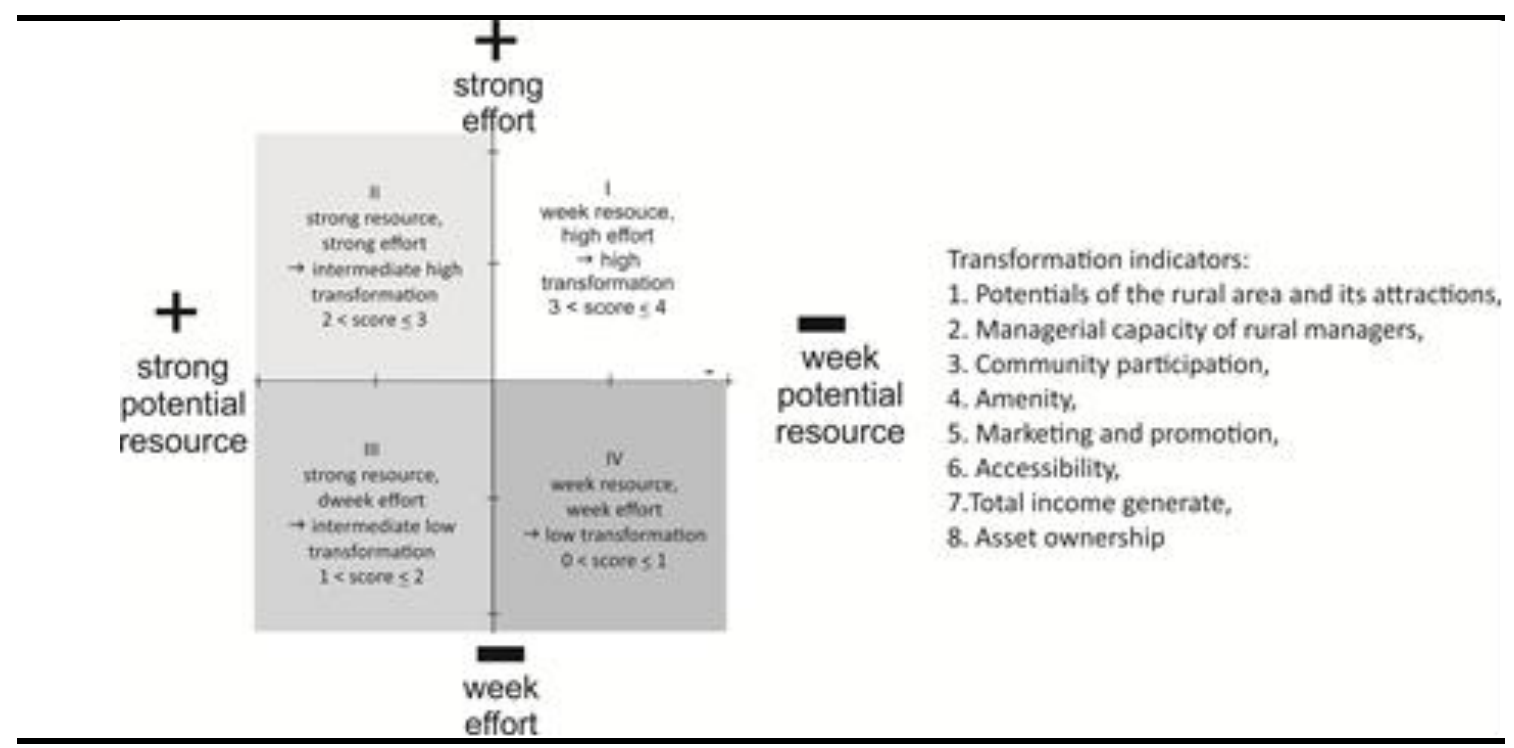

Source: Analisis, 2018

Figure 3. The quadrant model of analysis

\section{DISCUSSION}

\section{Qualitative Approach of Transformation Level}

The transformation level in qualitative approach was explored from observation, the interview, and discussion between the key informant and the community of each village. From those process, each indicator used could be explained the transformation of its village. However, in order to compare the level of transformation, it was needed a tool to measure differences in the level of its achievement, and one way to measure it, a quadrant model was used. (Table 2 and table 3).

Table 2. The Qualitative approach using quadrant model of Pentingsari and Gabugan Tourism Village

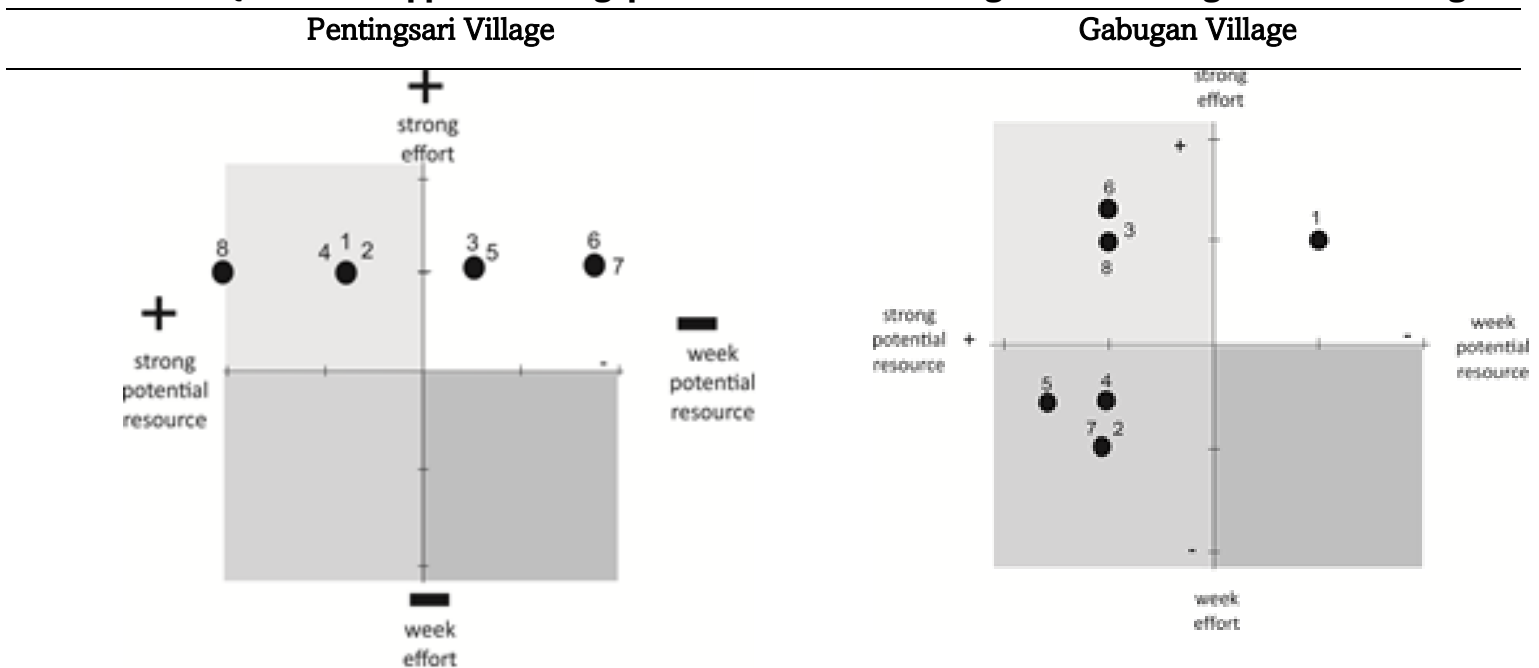




Pentingsari Village Gabugan Village

Result of Pentingsari Village qualitatively for each indicators:

1) Potentials of the rural area and its attractions

Good rural nature and culture that could be sold to local and foreign tourist

2) Managerial capacity of rural managers

Good management of Tourism Consciousness Organization (Pokdarwis), in collaboration with rural tourism management and the local leader

\section{3) Community participation}

The role of the local leader to encourage people's participation

4) Amenity

Interesting existing amenity that combines with the new ones

5) Marketing and promotion

The use of individual local leader network, mouth to mouth promotion, and the information technology to decrease the location's handicap

\section{6) Accessibility}

The isolated location could be changed to become a unique experience of tourism

7) Generated total income

The average tourist number increase to $87 \%$ per year, consistently reflects the generated income

8) Asset ownership

Individual asset and public asset used for community advantage with the income sharing proportionally
Result of Gabugan Village qualitatively for each indicator:

1) Potentials of the rural area and its attractions

Common rural nature and culture could be sold to local and foreign tourists

2) Managerial capacity of rural managers

The management of Tourism Consciousness Organization (Pokdarwis) and the rural tourism management have an obstacle in tradition aspect to be developed

\section{3) Community participation}

People participation handicapped by noble's tradition culture

\section{4) Amenity}

Interesting existing amenity combined with the shortage new amenity

5) Marketing and promotion

The good use of family network in big cities, mouth to mouth promotion, and the information technology, but poor coordination with the local leader

6) Accessibility

The location is quite easy to be reached, but not being used optimally

7) Generated total income

The average tourist number increase of $56 \%$ of tourists per year inconsistently reflects the uncertainty of additional income

8) Asset ownership

Individual asset and some of public asset used for tourist activity

Source: Analysis, 2018

\section{The quantification of qualitative approach}

It is difficult to compare the power of transformation among the village by qualitative approach without mixing it with quantitative data. In fact those four case studies needed different period of time in the transformation process. The time period of transformation was taken from the last significant change within the last ten years or before the observation, which was the time limit of the study. The value of transformation level was drawn from quadrant model using decimal number with the range between 0 to 4 , where 4 indicates the highest value of transformation and 0 for the lowest level of transformation. The quantification can be described as in table 4 and table 5 . 
Table 3. The Qualitative approach using quadrant model of Manding and Kasongan Industrial Village Manding Village Kasongan Village

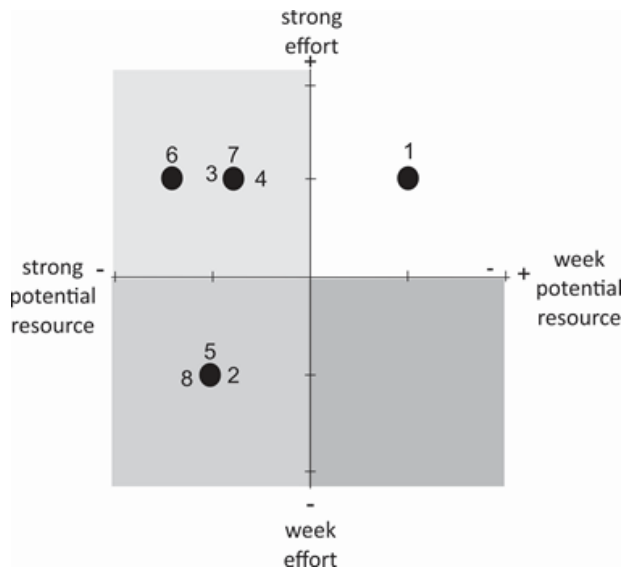

Result of Manding Village (Leather Craft) of qualitatively for each indicator:

1) Potentials of the rural area and its attractions

The shortage of agricultural potential encourage people to learn new skill of making leather craft

2) Managerial capacity of rural managers

Inactive of Pokdarwis and the rural tourism management because of the individual business domination

\section{3) Community participation}

Many craftsmen develop individual businesses and pay less attention to the effort of developing itself as industry communities

4) Amenity

There are 42 workshops in group I and 48 workshop in group II to support the industrial village

5) Marketing and promotion

The use of family network, mouth to mouth promotion, and the information technology, but poor coordination between the local leader

6) Accessibility:

The location is easy to be reached, but has less significant progress to improve

7) Generated total income

Total export increased of $6 \%$ per year inconsistently

8) Asset ownership

Individual asset and some of public asset used for tourist activity

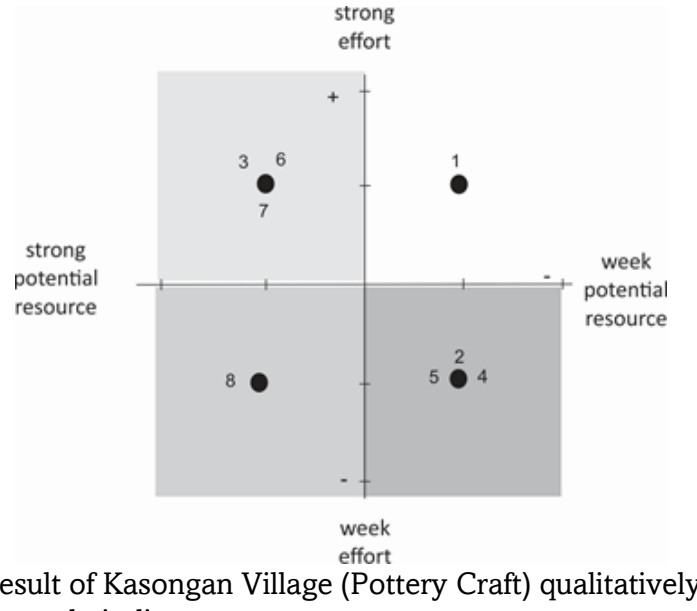
for each indicator:

1) Potentials of the rural area and its attractions

The shortage of agricultural potential encourage people to learn new skill of making pottery craft

2) Managerial capacity of rural managers

The business developed from the individual business, and change into a collective, but now it is being managed individually

3) Community participation

Many craftsmen develop individual businesses and pay less attention to develop as communities industry

4) Amenity

The community developed their business facilities individually, and pay less attention to the effort of developing itself as industry communities

5) Marketing and promotion

lack of awareness for the development of joint promotions

\section{6) Accessibility}

The location is easy to be reached, but has less significant progress to improve

7) Generated total income

Total export increased 6\% per year inconsistently

8) Asset ownership

Individual asset used for workshop and showroom while public asset (UPT Kasongan) are used for tourists workshop activity

Source: Analysis, 2018 
Table 4. The quantification of qualitative transformation

\begin{tabular}{|c|c|}
\hline $\begin{array}{c}\text { Pentingsari Village } \\
\end{array}$ & $\begin{array}{c}\text { Gabugan Village } \\
\end{array}$ \\
\hline $\begin{array}{l}\text { Transformation level }=(4 \text { indicators } \times 4)+(4 \\
\text { indicators } \times 3)=28 \text {. }\end{array}$ & $\begin{array}{l}\text { Transformation level }=(1 \text { indicator } \times 4)+(3 \\
\text { indicators } \times 3)+(4 \text { indicators } \times 2)=19\end{array}$ \\
\hline Transformation period 8 years. & Transformation period 11 years. \\
\hline Transformation level $=28 / 8=3.5$. & Transformation level $=19 / 11=1.73$ \\
\hline Score of 3.5 classified as high transformation. & $\begin{array}{l}\text { Score of } 1.73 \text { clasified as intermediate low } \\
\text { transformation. }\end{array}$ \\
\hline Manding Village & Kasongan Village \\
\hline $\begin{array}{l}\text { Transformation level }=(1 \text { indicator } \times 4)+(4 \text { indicator } \\
x 3)+(3 \text { indicator } \times 2)=22 . \\
\text { Transformation period } 16 \text { years. } \\
\text { Transformation level }=22 / 16=1.38 \text {. } \\
\text { Score of } 1.38 \text { classified as intermediate low } \\
\text { transformation }\end{array}$ & $\begin{array}{l}\text { Transformation level }=(1 \text { indicator } \times 4)+(3 \\
\text { indicators } \times 3)+(1 \text { indicator } \times 2)+(3 \text { indicators } \times 1)= \\
18 . \\
\text { Transformation period } 7 \text { years. } \\
\text { Transformation level }=18 / 7=2.57 \text {. } \\
\text { Score of } 2.57 \text { classified as intermediate high } \\
\text { transformation }\end{array}$ \\
\hline
\end{tabular}

Source: Analysis, 2018

As shown in table 4, Pentingsari reached the highest value level with 3.5 point which means it has high level of transformation (quadrant I). The point was achieved due to good process of transformation (28 point) and the short period of time to reach it (only 8 years). On the other hand, Manding had 22 point of transformation (near to the point of Pentingsari), but having a very long transformation period (22 years) has caused the value level of Manding to became low with the value of 1.38, and being classified as intermediate low (quadrant III). Conversely Kasongan village with the achievement of transformation value of 18, but managed to achieve it only within 7 years, so it reached the value of 2.57, which was grouped into intermediate high level (quadrant II). Gabugan village was similar to the condition that occurs in Manding with the final achievement of 1.73 , meaning that is classified as intermediate low, but qualitatively with different explanation of transformation process. Manding village which in the previous decade had made a good progress, in the next period had a saturated level so as it is difficult to improve the level of transformation, while in Gabugan case the cause of the low value of transformation was due to the tradition that was still held strong so it was still difficult to experience a transformation at a higher level. Therefore the model of the measuring tool designed to convert a qualitative approach into a more measurable and comparable one to another was valid enough to be used with qualitative explanations attached to obtain more accurate details.

From the total point of each village, Pentingsari was the highest, and is followed by Manding, Gabugan, and Kasongan. The research results underscored the most important indicators in achieving the high points of transformation, which were the roles of rural managers and community participation. Both indicators were the ones that strongly influence other indicators, because those two indicators showed the the role of human who were the central generator of the transformation itself. These two indicators could draw other indicators to be at a higher level. In the Pentingsari case the indicator of rural managers was in the quadrant II, while the community participation indicator was in the quadrant I. Other indicators are between quadrants I and II. In the Kasongan case on the other hand, the rural manager indicator was in quadrant IV whereas community participation in quadrant II. Other indicators are spread out between quadrants I to IV. This proves that both indicators influenced the other indicators. This indicates that this 
qualitative rural transformation tool is appropriate to distinguish the transformation levels in rural areas.

\section{Comparative Study of Area Surrounding the Case Study Area Using Quantitative Approach}

Long's quantitative approach also consider external driving force to determine the influence of urban-rural coordination level (Long et al., 2011), but this research used builtup areas map in the 10 years periods (2000 and 2010) (Figure 3) to depict the physical changes of surrounding case study with the aim of knowing whether the transformation of the villages was influenced by development of surrounding area. Due to the availability of the data, the map of surrounding case study was delineated from the area of 1,600 Ha of each case study.

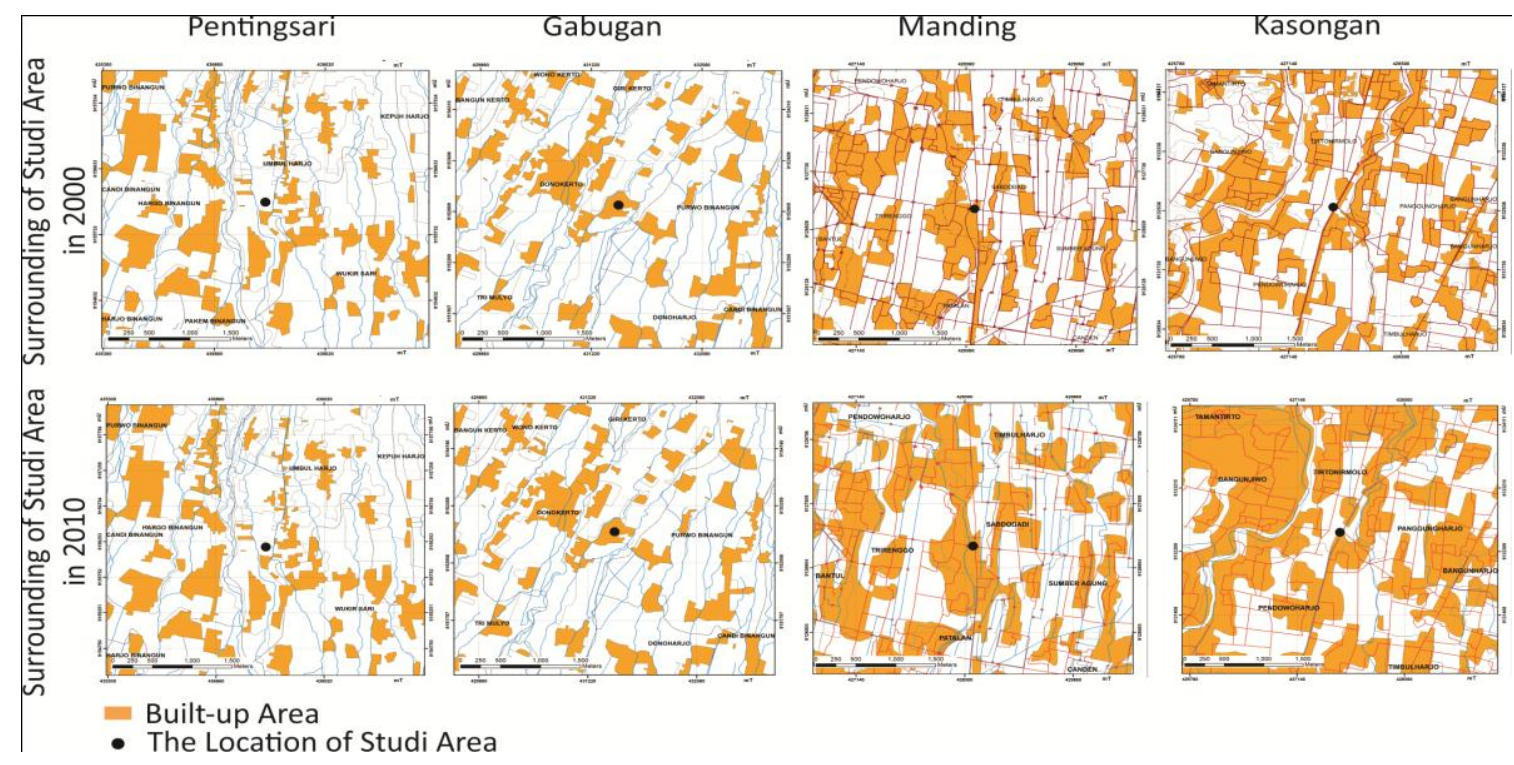

Source: Analysis, 2018 (from secondary data of satelite imagery 2000 and 2016)l change by comparing the non agricultural population

Figure 3. Built-up areas changing between 2000 and 2010 (Analysis, 2018)

Based on figure 3 and the secondary data from Biro Pusat Statistik of each district (kecamatan) 2002 - 2011 and summarized in Table 5a, it is possible to portray the development of each district on a macro basis. The result showed that in the last ten years, Bangunjiwo District experienced a rising of the built-up area by $55 \%$ and its population density by $29 \%$, which means that Kasongan Village in Bangunjiwo District is located in a fast growing area. It was the highest among other three study areas. This is understandable because Bangunjiwo is a residential development area, so that the built-up area and its population increase rapidly. The second highest was Sabdodadi District, which experienced a rising of the built-up area by $20 \%$, but its population density rose for only $7 \%$. It means that Manding's development is in an intermediate growing area of Sabdodadi District. In case of Sabdodadi, the high built-up area were dominated by the commercial area of the main street in Sabdodadi and the industrial area of workshop and showroom. But the population density is quite low since many people had moved to the big cities for better job opportunities. The third the Umbulharjo is the special case because the built up 
area below $1 \%$, but the growth of population density $19 \%$. The key informant said that many of villagers stay in other place even listed as residents of Umbulharjo. The smallest development is Donokerto. It is in the very low growing area, since the built-up area changes are below $1 \%$, but the growth of population density decreased $7 \%$. The utilization for agriculture is still a characteristic for the last two areas, but in a different way of transformation.

\section{Table 5. Comparative Study of Quantitative and Qualitative Approach}

5a. Analysis based on Quantitative Approach

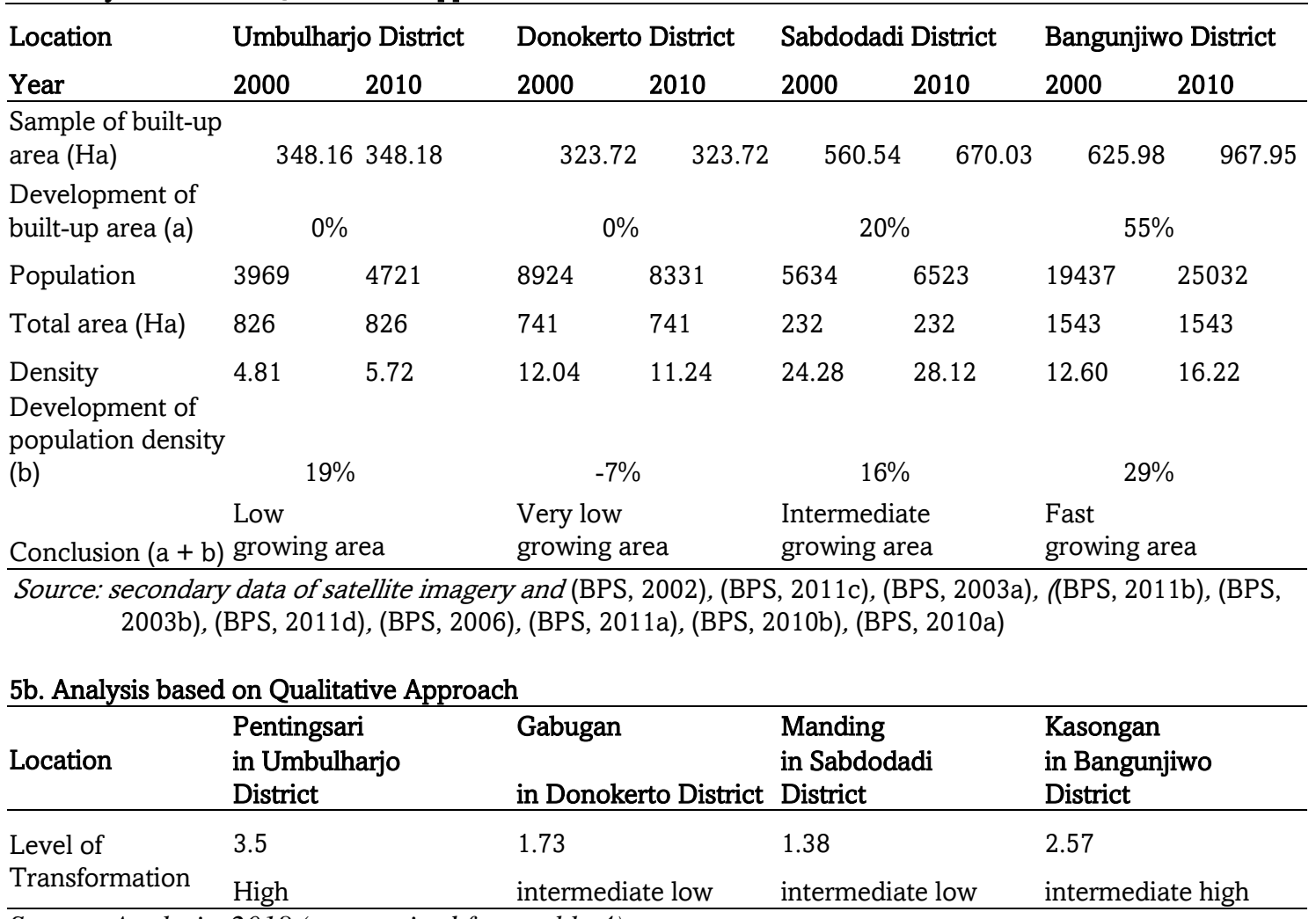

Source: Analysis, 2018 (summarized from table 4)

Compared with qualitative approach (Long et al., 2011), it can be concluded that the development of an physical area around rural area that were measured is not necessarily equal to the rate of transformation of a village. For example: Pentingsari, which is in a low development area using physical measurement model (Rana and Marwasta, 2015), if measured by qualitative measuring instrument, turned out to be at the high transformation level. This can happen considering that qualitative indicators are also included as factors that determine transformation. Employment structure change, one of Long (Long et al., 2011) indicator, were used to measure the Rural Transformation Level (RTL) by counting the proportion of laborers employment in farming, forestry, animal husbandary and fishery among total labourer. But in fact in Indonesia the farmer has another job in rural tourism in their village, so it is difficult to separate the agricultural job and the industrial job (such as tourism). Therefore this research is expected to fill the gap between quantitative and qualitative data. The eight indicators used were trying to complete a real picture of transformation measurement using the qualitative approach. 


\section{CONCLUSION}

As stated in the research objective, the study aims to explore tools to measure the level of transformation with a qualitative approach. This research clarifies that the tools of the qualitative approach can be used to explain the dynamics of rural transformation. Moreover, this research found the important key indicators which influenced the rural transformation, which were rural manager capacity and the community participation.

The comparison of qualitative and quantitative analysis showed different perspective of the result on the changes in the rural area. The quantitative approach, which is used to measure the dynamics of transformation in terms of the physical changes in the village, shows conclusions that are not always in line with transformation using qualitative approach. But the qualitative approach can answer the different trends of transformation between the two approaches. Quantitative analysis provides insight into the conditions surrounding the study area at the macro level, while qualitative analysis was applied to see in more detail the transformation that occurs at the mezzo and micro level. The contrasting results between the two provide an opportunity for researchers to deepen the cause of the difference. The difference in outcome of both approaches implies that the specific purpose of a qualitative tool for measuring rural transformation can be achieved.

\section{ACKNOWLEDGEMENT}

This paper is the result of research conducted with funding from the Slamet Rijadi Foundation through the University of Atma Jaya Yogyakarta Research Grant scheme for doctoral program. Author would like to grateful for university's support. Moreover, author also thank for the conversation with all of the key-informant persons who give valuable information for the study.

\section{REFERENCES}

Arsyad, L., Satriawan, E., Mulyo, J.H., \& Fitrady, A., 2011 Stategi Pembangunan Perdesaan Berbasis Lokal, Unit Penerbit Percetakan STIM YKPN, Yogyakarta.

Biro Pusat Statistik Kabupaten Bantul. (2002 and 2011). Kecamatan Kasihan dalam angka 2002 dan 2011, internet source URL https://bantulkab.bps.go.id/publication.html

Biro Pusat Statistik Kabupaten Sleman. (2003 and 2011). Kecamatan Cangkringan dalam angka 2003 dan 2011, internet source URL https://slemankab.bps.go.id/publication.html

Biro Pusat Statistik Kabupaten Sleman. (2003 and 2011). Kecamatan Turi dalam angka 2003 dan 2011, internet source URL https://slemankab.bps.go.id/publication.html

Biro Pusat Statistik Kabupaten Bantul. (2006 and 2011). Kecamatan Bantul dalam angka 2006 dan 2011, internet source URL https://bantulkab.bps.go.id/publication.html

Biro Pusat Statistik. (2010). Penduduk Indonesia Menurut Desa (Sensus 2010). internet source URL https://www.bps.go.id/website/fileMenu/Penduduk-Indonesia-Menurut-Desa-2010.pd

Biro Pusat Statistik. 2010 Migrasi Internal Penduduk Indonesia Hasil Sensus Penduduk 2010 internet source URL https://www.bps.go.id/publication/2012/05/23/9cd01b5265c6988245eca87a/migrasi-internalpenduduk-indonesia-hasil-sensus-penduduk-2010

Chen, L., Lin, S., \& Kuo, C. 2013 Rural tourism: Marketing strategies for the bed and breakfast industry in Taiwan, International Journal of Hospitality Management, Volume 32, March 2013, pp. 278-286

Dłużewska.A, Dłużewski, M. 2017 Tourism versus the transformation of ksours- Southern Morocco case study, Bulletin of Geography. Socio-economic Series No. 36 (2017), pp77-86.

Dogra, R., Gupta, A. (2012). Barriers to Community Participation in Tourism Development: Empirical Evidence from a Rural Destination, South Asian Journal of Tourism and Heritage, January 20125 No.1, pp. 129142.

Ezung, T.Z. 2011 Rural Tourism in Nagaland, India: Exploring the Potential, International Journal of Rural Management 7 (1\&2), pp. 133-147. 
Gibson, K., Cahill, A., \& McKay, D. 2010 rethinking the dynamics of rural transformation: performing different development pathways in a Philippine municipality. Transactions of the Institute of British Geographers, 35, 237-255.

Green, G.P. 2001 Amenities and Community Economic Development: Strategies for Sustainability, the Journal of Regional Analysis \& Policy (2001) 31:2, pp. 61-75.

Heejeong, Y. 2014 Spatial relationships of cultural amenities in rural tourism areas, Tourism Planning and Development, 2014 vol 11 No 4, pp. 452-462.

Hernández-Maestro,R, Muñoz-Gallego P.A, \& Santos-Requejo, L. 2009 Small-Business Owners' Knowledge and Rural Tourism Establishment Performance in Spain, Journal of Travel Research, 48 Number 1 August 2009, pp. 58-77.

Long, H., Zou, J., Pykett, J., \& Li, Y. 2011 Analysis of rural transformation development in China since the turn of the new millennium. Applied Geography, 31, 1094-1105.

McGee, T.G. 2008 Managing the Rural-urban Transformation in East Asia in the 21st century, Sustain Sci (2008) 3; pp. 155-167.

Nair, V., Mohamed, B., Chiun, L.M. 2015 Multi-Dimensional Responsible Rural Tourism Capacity (RRTC) Framework: A Proposed Environmental Responsibility and Management Model for Malaysia, AsiaPacific Journal of Innovation in Hospitality and Tourism, APJIHT 4 No. 1 March 2015 pp. 93-109.

Pudianti, A.; Syahbana, J.A.; Suprapti, A. 2015 Location as the Factor of Rural Transformation in Daerah Istimewa Yogyakarta, the 2nd Eco-Architecture Conference (EAC 2) proceeding, Qur'anic Science University, Wonosobo, 6-7- April 2015.

Purnamasari, L. S., Yudana, G., \& Rini, E. F. 2017 Spatial transformation of Surakarta's peripheral rural villages under in-situ urbanization phenomenon: the case of Gentan Village. Geoplanning: Journal of Geomatics and Planning, 4(1), 83-96.

Rana, S \& Marwasta D. 2015 Urbanisation trends in developing countries: Comparative study of Yogyakarta City and Kathmandu Valley, Journal of Natural Resources and Development 2015; 05: 29 - 36.

Rattanasuwongchai, N. 1998 Rural Tourism - the Impact on Rural Communities II, Thailand Bangkok, Food and Fertilizer Technology Centre for the Asian and Pacific Region, Database Extension Bulletin.

Reid, D.G., Mair, H \& Taylor, J, 2000 Community Participation in Rural Tourism Development, World Leisure Journal, 42, 2000-Issue 2, pp. 20-27.

Su, S.L... Jiang, Z.L., Zhang, Q \& Zhang, Y. 2011 Transformation of agricultural landscape under rapid urbanization: a threat to sustainability in Hang Jia-Hu region, China. Applied Geography, 31, 439-449.

UN Habitat. 2015 Habitat III Issue Papers: 10 - Urban Rural Linkages. New York.

Yin, R., 2009 Case Study Research: Design and Methods (fourth edition), Sage Publisher, Newbury Park CA. 